\begin{tabular}{|c|c|c|c|c|c|c|}
\hline \multirow{4}{*}{ Impact Factor: } & ISRA (India) & $=3.117$ & SIS (USA) & $=0.912$ & ICV (Poland) & $=6.630$ \\
\hline & ISI (Dubai, UAE & $=0.829$ & РИНЦ (Russia & $=0.156$ & PIF (India) & $=1.940$ \\
\hline & GIF (Australia) & $=0.564$ & ESJI (KZ) & $=8.716$ & IBI (India) & $=4.260$ \\
\hline & JIF & $=1.500$ & SJIF (Morocco & $=\mathbf{5 . 6 6 7}$ & OAJI (USA) & $=0.350$ \\
\hline
\end{tabular}

\section{SOI: $\underline{1.1 / T A S}$ DOI: $\underline{10.15863 / T A S}$ \\ International Scientific Journal Theoretical \& Applied Science}

p-ISSN: 2308-4944 (print) e-ISSN: 2409-0085 (online)

Year: 2019 Issue: $04 \quad$ Volume: 72

Published: $30.04 .2019 \quad$ http://T-Science.org

Section 31. Economic research, finance, innovation, risk management.
QR - Issue

QR - Article

\title{
DEVELOPMENT OF ENSURING A RESOURCE BASE OF JOINT- STOCK BANKS BASED ON INNOVATIONS
}

Abstract: The article discusses the development of the provision of resource base of joint-stock banks on the basis of innovation in Uzbekistan. The author has done a statistical analysis of the structure of commercial banks in Uzbekistan, and identified the main indicators of the credit operation. Based on the econometric analysis, the main factors affecting the efficiency of lending and small business development are identified.

Key words: innovation, credit, joint-stock banks, small business, benefits, operations, resource base.

Language: English

Citation: Isaeva, N. H. (2019). Development of ensuring a resource base of joint-stock banks based on innovations. ISJ Theoretical \& Applied Science, 04 (72), 413-420.

Soi: http://s-o-i.org/1.1/TAS-04-72-52 Doi: roskef https://dx.doi.org/10.15863/TAS.2019.04.72.52

\section{Introduction}

One of the main obstacles to the development of the banking system of the Republic of Uzbekistan is to improve the quality of banking services, expand the range of services and bring them to the level of developed banks.

The head of our state said in particular that it is necessary to pay special attention to the development of modern banking services and popularization of banking services. The Strategic Action Strategy for the five main priorities of Uzbekistan's development in 2017-2021, adopted by the Presidential Decree of 7 February 2017, intensification of banks' capitalization and increasing the stability of their deposit base, strengthening their financial stability and credibility, promising investment $\mathrm{n}$ projects and small businesses and entrepreneurship". [1]

A number of measures have been undertaken to accomplish this task. As of January 1, 2018, the number of users of Remote Control Systems of the Bank exceeded 2042 111. Thus, the number of users of the "Internet Banking" and "Bank-Client" software systems is 135629 , and their number increased by 1.9 times compared to the beginning of 2016. [2] Nevertheless, we can see that the use of banking services and its popularity are somewhat weak in our country as compared to some developed countries, and the mechanism for implementing services is not sufficiently improved. The Resolution of the President of the Republic of Uzbekistan "On Additional
Measures to Increase Public Officership of Banking Services" No. PP-3620 of 23 November 2018 also emphasized this fact. The Resolution states that the current problem in the banking system is that the retail banking services market does not have a low level of development and there are no modern approaches to establishing partnerships with clients. The decree sets out the best international practices of banking, as well as the introduction of new types of banking services and products.

Indeed, the development of the services market in commercial banks not only allows the distribution of capital to the population, but also informing the population, accelerating payments, and many other conveniences and opportunities. In this regard, the experience of foreign countries in the field of retail banking services and the introduction of positive experience of this experience in the banking system of our country is one of the urgent issues of today.

\section{Analysis and results}

Dynamics and current state of the assets of commercial banks of the Republic of Uzbekistan Development of scientific recommendations and practical recommendations aimed at optimizing the composition of assets of commercial banks of the Republic of Uzbekistan, formation of scientific conclusions requires the assessment of the actual composition of assets in terms of liquidity, profitability and risk. we will evaluate. [3] 


\begin{tabular}{|c|c|c|c|c|c|c|}
\hline \multirow{4}{*}{ Impact Factor: } & ISRA (India) & $=3.117$ & SIS (USA) & $=0.912$ & ICV (Poland) & $=6.630$ \\
\hline & ISI (Dubai, UAE & $=0.829$ & РИНЦ (Russia & $=\mathbf{0 . 1 5 6}$ & PIF (India) & $=1.940$ \\
\hline & GIF (Australia) & $=0.564$ & ESJI (KZ) & $=8.716$ & IBI (India) & $=4.260$ \\
\hline & JIF & $=1.500$ & SJIF (Morocco & $=5.667$ & OAJI (USA) & $=0.350$ \\
\hline
\end{tabular}

Table 1. Structure of assets of commercial banks of the Republic of Uzbekistan

\begin{tabular}{|l|l|l|l|l|l|}
\hline \multirow{2}{*}{ Actives } & \multicolumn{5}{c|}{ Years } \\
\cline { 2 - 6 } & \multicolumn{1}{|c|}{$\mathbf{2 0 0 9}$} & \multicolumn{1}{c|}{$\mathbf{2 0 1 0}$} & \multicolumn{1}{c|}{$\mathbf{2 0 1 1}$} & $\mathbf{2 0 1 2}$ & \multicolumn{1}{c|}{$\mathbf{2 0 1 3}$} \\
\hline Cash and other cash transactions & 2,97 & 2,38 & 2,98 & 2,99 & 2,42 \\
\hline $\begin{array}{l}\text { Funds in the Central Bank of the } \\
\text { Republic of Uzbekistan }\end{array}$ & 21,11 & 20,87 & 15,74 & 16,69 & 14,42 \\
\hline Funds from other banks & 13,2 & 13,82 & 17,31 & 17,99 & 16,31 \\
\hline Securities are in pure condition & 0,42 & 0,39 & 0,43 & 0,1 & 0,14 \\
\hline Investments & 1,68 & 3,04 & 2,71 & 2,44 & 2,49 \\
\hline $\begin{array}{l}\text { Securities purchased on a re-sale } \\
\text { basis }\end{array}$ & 0,08 & 0,04 & 0,03 & 0,02 & 0 \\
\hline $\begin{array}{l}\text { Loans and lease transactions are in } \\
\text { good condition }\end{array}$ & 51,68 & 48,43 & 50,25 & 50,28 & 56,22 \\
\hline $\begin{array}{l}\text { Responsibilities of customers on } \\
\text { financial instruments }\end{array}$ & 0,9 & 2,16 & 2,31 & 1,55 & 1,11 \\
\hline Basic tools are pure & 3,33 & 3,22 & 3,27 & 3,28 & 3,07 \\
\hline Funds on calculated accounts & 0,65 & 0,65 & 0,61 & 0,62 & 0,59 \\
\hline Others & 3,9 & 5,0 & 4,36 & 4,04 & 3,23 \\
\hline
\end{tabular}

Source: The author estimates the author's data on the Central Bank of the Republic of Uzbekistan.

Table 1 shows that in the period 2009-2013 the share of assets of commercial banks of the Republic occupies the first place. This is explained by the fact that lending is the main type of activity for banks. As noted in the structure of assets of commercial banks of the Republic of Uzbekistan, the share of loan and leasing operations was $48.43 \%$ in 2010 and $50.25 \%$ in 2011 In 2012 amounted to $50.28 \%$ and $56.22 \%$ in 2013. The volume of these operations increased by $4.54 \%$ in 2013 compared to 2009. Commercial banks' assets are subsequently repaid in the Central Bank and other commercial banks. In 2009, the funds of the Central Bank of the Republic of Uzbekistan amounted to $21.11 \%$ of total assets, while in 2013 it decreased to $14.42 \%$ of total assets. And in 2012 it was $16.69 \%$. In other banks, funds in contrast to total assets in 2009 were $13.20 \%$, while their share in 2013 increased to $16.31 \%$. And in 2012 it was $17.99 \%$. Following the lending operations in the structure of assets of commercial banks, the main reasons for borrowing funds in the Central Bank of the Republic of
Uzbekistan and other commercial banks are the availability of requirements for commercial banks to reserve reserves in the Central Bank of the Republic of Uzbekistan and the development of interbank market in Uzbekistan. Stable position of the banks of the country is the confidence in the banking system, in particular, oh the volume of deposits of the population and business entities in commercial banks has increased by $30.2 \%$ compared with the beginning of 2013, As of January 1, $26.1 \mathrm{trln}$. soum. Also, within the framework of the measures to create a long-term resource base in the banks, the issue of issuance of bank securities, which is one of the financial tools for attraction of free funds to the banks, was also accelerated. As of January 1, 2014, the circulation was made by banks, Savings and savings certificates of commercial banks placed among businesses amounted to 592 billion soums The long-term bonds of commercial banks, placed among investors, amounted to $\$ 330$ billion. soums.

Table 2. Main Indicators of Credit Operations of the Banking Sector (in\%)

\begin{tabular}{|l|l|l|l|l|l|}
\hline Indicators & \multicolumn{4}{|c|}{ Years } \\
\cline { 2 - 5 } & $\mathbf{2 0 0 9}$ & $\mathbf{2 0 1 0}$ & $\mathbf{2 0 1 1}$ & $\mathbf{2 0 1 2}$ & $\mathbf{2 0 1 3}$ \\
\hline Loan portfolio-total & 100,0 & 100,0 & 100,0 & 100,0 & 100,0 \\
\hline Loans to nonbank financial institutions and enterprises & 83,89 & 82,88 & 87,97 & 82,03 & 80,03 \\
\hline Loans to other banks & 0,02 & 0,01 & 0 & 0 & 0 \\
\hline Loans to government institutions & 0,001 & 0 & 0 & 0 & 0 \\
\hline Loans to individuals & 16,08 & 17,11 & 17,03 & 17,97 & 19,96 \\
\hline
\end{tabular}

As it is seen from the table data, loans to nonfinancial organizations and enterprises in the loan portfolio have a tendency to decline. In 2009, the share of loans extended to non-financial organizations and enterprises in the loan portfolio made up $83.89 \%$, which is $80.03 \%$ in 2013 , which declined by $3.86 \%$. One of the main reasons for this is the growth in the number of loans issued by individuals to commercial 


\begin{tabular}{|c|c|c|c|c|c|c|}
\hline \multirow{4}{*}{ Impact Factor: } & ISRA (India) & $=3.117$ & SIS (USA) & $=0.912$ & ICV (Poland) & $=6.630$ \\
\hline & ISI (Dubai, UAE & $=0.829$ & РИНЦ (Russia & $=\mathbf{0 . 1 5 6}$ & PIF (India) & $=1.940$ \\
\hline & GIF (Australia) & $=0.564$ & ESJI (KZ) & $=8.716$ & IBI (India) & $=4.260$ \\
\hline & JIF & $=1.500$ & SJIF (Morocco & $=5.667$ & OAJI (USA) & $=0.350$ \\
\hline
\end{tabular}

banks for many years. More precisely, this indicator indicates that today the demand for loans by individuals, such as consumer loans, mortgages and others, is rising. In the structure of credit portfolio of commercial banks, the share of loans to state-owned and other banks is almost $0 \%$. This, in turn, pays great attention to this area and emphasizes that the loans given to this sector are more reliable than other sectors. At the same time, the smaller size of these indicators means that today the development of the interbank resources market is one of the pressing issues.

Table 2. Securities of commercial banks.

\begin{tabular}{|c|c|c|c|c|c|c|c|c|c|c|}
\hline & \multicolumn{2}{|l|}{2009} & \multicolumn{2}{|l|}{2010} & \multicolumn{2}{|l|}{2011} & \multicolumn{2}{|l|}{2012} & \multicolumn{2}{|l|}{2013} \\
\hline & $\begin{array}{l}\text { billion } \\
\text { soums }\end{array}$ & $\%$ & $\begin{array}{l}\text { billion } \\
\text { soums }\end{array}$ & $\%$ & $\begin{array}{l}\text { billion } \\
\text { soums }\end{array}$ & $\%$ & $\begin{array}{l}\text { billion } \\
\text { soums }\end{array}$ & $\%$ & $\begin{array}{l}\text { billion } \\
\text { soums }\end{array}$ & $\%$ \\
\hline Total investments & 226,84 & 100 & 484,52 & 100 & 590,8 & 100 & 661,9 & 100 & 858,9 & 100 \\
\hline of which: & & & & & & & & & & \\
\hline trading portfolio & 46,76 & 20,61 & 55,52 & 11,46 & 82,9 & 14,04 & 25,5 & 3,85 & 47,2 & 5,5 \\
\hline $\begin{array}{l}\text { investment } \\
\text { portfolio }\end{array}$ & 180,08 & 79,39 & 428,99 & 88,54 & 507,9 & 85,96 & 636,5 & 96,15 & 811,6 & 94,50 \\
\hline
\end{tabular}

During 2009-2013, there was a structural shift in the share of commercial banks' securities. In 2013, the investment portfolio of commercial banks amounted to $94.50 \%$ of the total portfolio. The reason for this change was the fact that on the basis of the report on the results of the year 20 rating agency "AhborReyting" was put on the market. and the active participation of commercial banks in the establishment of new enterprises and organizations in different sectors of the economy. In general, the share of commercial banks in the securities market was at a slow pace, and amounted to 858.9 billion sums in 2013. As compared to 2009 , this indicator increased almost 4 times. It is important to study the role of credit investments in GDP in assessing the role of commercial banks in the activities of commercial banks. [4,5]

Table 4. Dynamics of commercial banks' credit investments

\begin{tabular}{|c|c|c|c|c|c|c|}
\hline Indicators & 01.01.2010 & 01.01.2011 & 01.01.2012 & 01.01.2013 & 01.01.2014 & $\begin{array}{l}\text { Change in } \\
\text { January } 1, \\
2014 \\
\text { compared to } \\
\text { January } 1, \\
2009\end{array}$ \\
\hline $\begin{array}{l}\text { GDP } \quad \text { (trillion } \\
\text { soums) }\end{array}$ & 48,9 & 61,8 & 77,8 & 96,6 & 119,0 & 70,1 \\
\hline $\begin{array}{l}\text { Loan Deposits to } \\
\text { GDP (in\%) }\end{array}$ & 17,8 & 18,9 & 20,1 & 21,3 & 22,3 & 4,5 \\
\hline
\end{tabular}

The table data shows that during the period of 2009-2013 there was an increase in the share of credit investments and their share in GDP. This, of course, is a positive phenomenon, indicating a high share of loans in the development of our economy and their contribution to the development of the economy. At the same time, in order to further improve the practice of lending to commercial banks, we consider it appropriate to apply the following scientific recommendations and practical recommendations: Setting up the network limits on their credit policy.
Central Bank of the Republic of Uzbekistan established the author's calculations.

The level of diversification of the loan portfolio of the commercial banks of the Republic should be increased. Over 25 per cent of commercial bank loans are concentrated in a single-industry enterprise, indicating a low level of diversification of the bank's loan portfolio and increased credit risk. table data, analyzing the assets of OAITB "Silk Road" and their share of loans. [6] 


\begin{tabular}{|c|c|c|c|c|c|c|}
\hline \multirow{4}{*}{ Impact Factor: } & ISRA (India) & $=3.117$ & SIS (USA) & $=0.912$ & ICV (Poland) & $=6.630$ \\
\hline & ISI (Dubai, UAE & $=0.829$ & РИНЦ (Russia & $=\mathbf{0 . 1 5 6}$ & PIF (India) & $=1.940$ \\
\hline & GIF (Australia) & $=0.564$ & ESJI (KZ) & $=8.716$ & IBI (India) & $=4.260$ \\
\hline & JIF & $=1.500$ & SJIF (Morocco & $=5.667$ & OAJI (USA) & $=0.350$ \\
\hline
\end{tabular}

Table 5. Indicators of assets of the OJSC Ipak Yoli Bank

\begin{tabular}{|l|c|c|c|c|}
\hline \multicolumn{1}{|c|}{ Indicators } & $\mathbf{2 0 1 0 ~ y .}$ & $\mathbf{2 0 1 1} \mathbf{~ y .}$ & $\mathbf{2 0 1 2} \mathbf{~ y .}$ & $\mathbf{2 0 1 3} \mathbf{~ y . ~}$ \\
\hline Total assets, bln UZS & 522,6 & 638,8 & 816,5 & 1014,5 \\
\hline Loan portfolio, bln UZS & 185,2 & 273,9 & 333,9 & 423,5 \\
\hline The share of loans in assets, in percentages & 35,4 & 42,9 & 40,9 & 41,7 \\
\hline
\end{tabular}

The above table shows that the assets of the OAITB Silk Road Bank have been growing over the years. At the same time, the amount of loans has grown over the years. However, the share of bank loans in assets is slightly lower than other commercial banks. The share of loans in assets in 2010 amounted to $35.4 \%$, which is $41.7 \%$ in 2013 . The author has been identified by the Ipak Yuli Bank on the balance sheet data. [7]

One of the main indicators characterizing the quality of assets of commercial banks is the indicator of profitability of actives. One of the key factors affecting profitability of assets is the change in the share of non-profitable assets. Assessment of the Return on Assets of Commercial Banks According to the recommendations of the experts of the International Bank for Reconstruction and
Development, interest income should be at least $70 \%$ of the total gross profit of commercial banks. Experts of the bank believe that interest income of commercial banks should consist of the following elements: Interest received from deposits placed in other banks; [8] - Revenues from securities with a fixed rate; The following table shows that interest income from loans, deposits, and other funds placed in the structure of banks' revenues is high, in $2009-56.42 \%$, in 2013 $59 \%$, Which is $76 \%$. Revenues from commercial operations and revenues from investment in the structure of banks' revenues have the lowest rates, while revenues from investment have increased in 2011, which has increased by 1.46 percent in total revenues. In 2012, revenues from investment in 2011 decreased by 0.19 percentage points and in 2013 to 0.39 percentage points versus 2011. [9]

Table 6. Income structure of commercial banks of the Republic of Uzbekistan

\begin{tabular}{|c|c|c|c|c|c|c|}
\hline № & Income & 2009 y. & 2010y. & 2011y. & $2012 y$. & $2013 y$. \\
\hline 1 & $\begin{array}{l}\text { Interest received from } \\
\text { placement of loans, } \\
\text { deposits and other funds }\end{array}$ & 56,42 & 56,87 & 56,17 & 57,46 & 59,76 \\
\hline 2 & Commission income & 34,70 & 33,18 & 33,91 & 31,97 & 29,91 \\
\hline 3 & $\begin{array}{l}\text { Income from foreign } \\
\text { currency }\end{array}$ & 4,65 & 4,55 & 3,43 & 3,43 & 4,25 \\
\hline 4 & $\begin{array}{l}\text { Income from trading } \\
\text { operations }\end{array}$ & 0,02 & 0,0001 & 0,0007 & 0,0008 & 0,0016 \\
\hline 5 & Income from investment & 0,48 & 0,91 & 1,46 & 1,27 & 1,07 \\
\hline 6 & Other Income & 3,78 & 4,49 & 5,03 & 5,25 & 5,00 \\
\hline \multicolumn{2}{|c|}{ TOTAL } & 100,0 & 100,0 & 100,0 & 100,0 & 100,0 \\
\hline
\end{tabular}

At the same time, commissions' revenues in the structure of revenues of commercial banks are also significantly higher. In 2009, commercial banks' comission revenues totaled $34.70 \%$, while in 2013 this figure dropped $4.79 \%$. Experts of the International Bank for Reconstruction and Development (EBRD) noted that the share of interest-earning loans in total interest revenues should be no less than $60 \%$ need to think. For this purpose, the share of commercial banks in the volume of brutto loans should not be less than $60 \%$. Therefore, it is important to determine the reasons for the change in the share of interest income in the gross incomes, and to develop measures to prevent its sharp decline., as well as the high level of passivity of the analytical report on the banking sector of the rating agency "Ahbor-Reyting". You may also be assessed. The reason for this is that as a rule, commercial banks, which do not have their own resource base, use commercial banks as a source of interbank loans. The reason of this situation is that commercial banks with profitable projects attract loans from other banks and earn higher profits by lending their investment projects. The Bank has been one of the factors directly affecting profitability and liquidity of banks' assets, Today, mandatory reserve requirements are used as one of the most important instruments of monetary policy in the regulation of money supply through the impact on the credit resources of commercial banks. In particular, in 2013, based on the forecasted inflation and cash outflow indicators, in order to expand the long-term resource base in the banks, the use of diversified reserve requirements was used for commercial purposes For legal entities attracted by banks, deposits were withdrawn for 15 years and up to 1 year - for deposits up to 15 percent, for deposits with 1 year to 3 years - 


\begin{tabular}{|c|c|c|c|c|c|c|}
\hline \multirow{4}{*}{ Impact Factor: } & ISRA (India) & $=3.117$ & SIS (USA) & $=0.912$ & ICV (Poland) & $=6.630$ \\
\hline & ISI (Dubai, UAE & $=0.829$ & РИНЦ (Russia) & $=0.156$ & PIF (India) & $=1.940$ \\
\hline & GIF (Australia) & $=0.564$ & ESJI (KZ) & $=8.716$ & IBI (India) & $=4.260$ \\
\hline & JIF & $=1.500$ & SJIF (Morocco & $=5.667$ & OAJI (USA) & $=0.350$ \\
\hline
\end{tabular}

for 12 percent, for deposits with a maturity of more than 3 years - at 10.5 percent. The volume of mandatory reserves of the Central Bank amounted to 463.1 billion soums. The amount of mandatory reserve is reflected in the separate account of the commercial banks (account 10309), which is $6.0 \%$. This means that interest rates on the deposit market have fallen. The interest rate index also dropped by 1.56 percentage points in 2013 compared to 2009 . The share of interest income in income-generating assets in 2009 was 10.6 percent in 2013 , down 0.72 percent to 9.88 percent. The share of interest expense on interest bearing liabilities increased by 0.85 percentage points in 2013 compared to 2009. In 2013, the share of income-generating assets in total assets increased by 8.42 percent compared to 2009 . That is, in 2009 this figure was $67.8 \%$, in $2013-76.22 \%$. The table below analyzes the income-generating assets of OATB Kapitalbank. [10]

At present, the profitability of commercial banks is being used in the following areas: distributed among founders; dividends to shareholders; payments to the budget are being made; distributed among bank staff; Increasing the bank capital (capitalization); special and general reserve funds of the bank are being created.

Short-term bonds and medium-term treasury liabilities), the Central Bank's bonds are recognized. The exemption from taxation of profits of investors from government securities will increase their investment attractiveness. Cash flows of commercial banks in the Republic of Kazakhstan, in contrast to the banking practice of developed foreign countries, are an asset that directly and indirectly affects the profitability of the Bank's assets. Their direct impact on the profitability of bank assets is reflected in the fact that the cashless payments to the cashier and the expense are not paid by the customers. Reducing the amount of mandatory reserves to cashless cash in a turnover cashcourse of a bank means indirect effects of cash inflows on the bank's assets. This is because the reduction of the amount of mandatory reserves is the increase in the amount of banking resources. There are no Nostro correspondent accounts in national currencies of the country's commercial banks in the composition of cash assets of commercial banks in the Republic of Uzbekistan. In most developed foreign countries and in many CIS member states, including deposits in profit-making assets, The Russian Federation, the Republic of Kazakhstan, the Kyrgyz Republic and Tajikistan in the Republic of Turkey, each commercial bank has two Nostro representative accounts in national currency. One of them is opened on the balance of the Central Bank of the country and is called vertical representation account. The second one is the horizontal correspondent account opened with the balance of other commercial banks in the country. [9,10]
All operations of commercial banks with other banks are carried out only through horizontal correspondent accounts. This, in turn, accelerates the payment process and helps to increase their efficiency. Commercial banks of the Republic of Uzbekistan do not have horizontal correspondent accounts, which negatively affects the effectiveness of payments through banks. Therefore, we would like to invite commercial banks to open horizontal correspondent accounts in national currency by the Central Bank. At the same time, it is necessary to strengthen control over the interbank operations by the Central Bank. Formation of the assets of commercial banks in accordance with the principle of declining liquidity varies greatly from the order of formation of existing assets in the international banking practice. In the structure of assets of commercial banks of the Republic of Uzbekistan, the second place is cash assets, third place is the main instruments, the last, the fourth and securities in the form of securities. In the banking sector of the developed foreign countries, the second one after the credits occupies the form of securities, while the share of cash assets occupies the third place in the structure of assets. The absolute majority of all commercial banks' securities are invested in government short-term bonds and medium-term treasury coming. For example, as of January 1, 2011, the total amount of investments made by banks of the Republic of Uzbekistan to securities amounted to 55.4 billion soums. The share of investments in government securities amounted to $83.1 \%$. The main reason for this is that, first of all, the payment in the UDC is guaranteed; Secondly, banks' profits from the SDRP are not taxable. At the same time, this situation shows that our republic has not developed securities transactions with commercial banks. Short-term government short-term bonds, which are the source of non-inflationary deficit of state budget deficit, have been put into circulation since March 1996. Since then, the government's shortterm bond market has grown rapidly and in the short run it has become one of the major segments of the financial market. In the initial stages of development of the DKMO market only 3-month bonds were issued, then 6-9 and 12-month bonds were issued. Rapid growth of the DGMO market. The absence of discount transactions in the banking practice of our country was estimated by the author on the basis of the statistical data of the Central Bank of Uzbekistan to increase the profitability of assets of commercial banks. Significantly adversely affected. Because discounting operations enable banks to receive significant interest income. In addition, discounting operations will increase the liquidity of banks, without damaging the profitability of assets of commercial banks. This option is generated by recalculation of the balances of commercial banks in the Central Bank. Thus, the lack of discount operations in the banking practice of the republic negatively affects the liquidity 


\begin{tabular}{|c|c|c|c|c|c|c|}
\hline \multirow{4}{*}{ Impact Factor: } & ISRA (India) & $=3.117$ & SIS (USA) & $=0.912$ & ICV (Poland) & $=6.630$ \\
\hline & ISI (Dubai, UAE & $=0.829$ & РИНЦ (Russia & $=0.156$ & PIF (India) & $=1.940$ \\
\hline & GIF (Australia) & $=0.564$ & ESJI (KZ) & $=8.716$ & IBI (India) & $=4.260$ \\
\hline & JIF & $=1.500$ & SJIF (Morocco & $=5.667$ & OAJI (USA) & $=0.350$ \\
\hline
\end{tabular}

of commercial banks and increases the profitability of their assets. Forfeiting operations of commercial banks enable them to achieve considerable profits. [13]

The reason for this is that in the off-shift operations commercial bills are accounted for without a regressive right, so the discount rate of banks is high.2.3. In the second part of the study, the following conclusions were drawn up in the light of the survey: - Loans occupy the first place in the structure of assets of commercial banks of the republic for the period of 2009-2013. This is due to the fact that lending is the main type of activity for banks. The share of loans and leasing operations in the structure of assets of commercial banks of the Republic of Uzbekistan is high, in 2010 it amounted to $48.43 \%$, in 2011 it was $50.25 \%, 28$ percent and 56.22 percent in 2013 . The volume of these transactions increased by $4.54 \%$ in 2013 compared to 2009. - Loans to non-financial organizations and enterprises in the loan portfolio had a tendency to decline. In 2009, the share of loans extended to non-financial organizations and enterprises in the loan portfolio made up $83.89 \%$, which is $80.03 \%$ in 2013 , which declined by $3.86 \%$. One of the main reasons for this is the growth in the number of loans issued by individuals to commercial banks for many years. In particular, this indicator indicates an increase in the demand for individuals, such as consumer loans, mortgages, and other types of loans. In the period of 2009-2013, there was a tendency for credit investments and their share in GDP. This, of course, is a positive phenomenon, indicating a high share of loans in the development of our economy, and their contribution is growing from year to year. Commissions in revenues of commercial banks are also significantly higher. In 2009, the share of commercial banks' revenues in total revenues amounted to $34.70 \%$, while in 2013 this figure dropped to $4.79 \%$. It is one of the factors directly affecting profitability and liquidity of assets of commercial banks. The return on assets of the bank (ROA) in 2009 was $2.6 \%$, in 2013 it was $1.59 \%$. However, it should be noted that the profitability of the bank's assets in 2011 increased from $1.47 \%$ in 2012 to $1.49 \%$. The return on equity (ROE) of banks in 2009 was 15.0 percent, in 2013 - 13.73 percent. - In the structure of income-generating assets of OJSCB Kapitalbank there is a high share of loans, in comparison with 2009, 232.8 billion soums. This indicates that today the practice of credit operations in the structure of interest-earnings of commercial banks is important. In other words, credit operations are the main sources of income for commercial banks. Credit and leasing operations have a high share in the structure of interest-earnings in the OATBlooksbank, its share at the beginning of this year is $75.40 \%$. This, in turn, illustrates the role of credit operations in the formation of commercial banks' revenues. [11]

As a result of large-scale reforms in financial support of entrepreneurship, the volume of loans provided by commercial banks and the volume of provided microfinance services grow from year to year. In particular, the volume of credit resources allocated to small business and private entrepreneurship from all sources in 2017 amounted to 19564.0 billion soums. At the same time, the volume of microcredits increased by 3.6 times and amounted to 4015.0 billion soums. soums (Table 1). [12] In particular, in 2017, 490.3 billion soums will be allocated for the development of family entrepreneurship and craftsmanship. UZS 2782.2 billion for the development of women's entrepreneurship. UZS 3381.4 bn., for foodstuffs production. The enterprises producing non-food products accounted for UZS 3915.8 bn. UZS 360.2 billion to finance business projects of graduates of professional colleges. The bank has allocated loans worth a total of over 2 billion soums.[14]

Table 7. Volume of Loans of Commercial Banks to Small Business and Private Entrepreneurship, UZS bn. soums

\begin{tabular}{|c|c|c|c|c|}
\hline \hline Years & $\begin{array}{c}\text { CME production } \\
\text { and services (Y1), } \\
\text { bn. soums }\end{array}$ & $\begin{array}{c}\text { Loans to } \\
\text { commercial banks } \\
\text { Investments, bn. } \\
\text { soums }\end{array}$ & $\begin{array}{c}\text { By commercial banks } \\
\text { small business } \\
\text { loans, bn. soums (X1) }\end{array}$ & $\begin{array}{c}\text { By commercial banks } \\
\text { small businesses } \\
\text { microfinance services (X2), } \\
\text { billion soums }\end{array}$ \\
\hline 2010 y. & 32753,86 & 11539,3 & 2700,0 & 485,2 \\
\hline 2011 y. & 42532,67 & 15651,5 & 4000,0 & 752,3 \\
\hline 2012 y. & 52881,82 & 20392,0 & 5346,0 & 1023,0 \\
\hline 2013 y. & 65990,38 & 26530,0 & 6982,0 & 1366,0 \\
\hline 2014 y. & 81382,29 & 34809,0 & 9158,0 & 1907,0 \\
\hline 2015 y. & 97415,31 & 42685,0 & 12112,0 & 2526,0 \\
\hline 2016 y. & 108996,4 & 53400,0 & 15870,1 & 3326,0 \\
\hline 2017 y. & 139469,7 & 110600,0 & 19564,0 & 4015,0 \\
\hline
\end{tabular}




\begin{tabular}{|c|c|c|c|c|c|c|}
\hline \multirow{4}{*}{ Impact Factor: } & ISRA (India) & $=3.117$ & SIS (USA) & $=0.912$ & ICV (Poland) & $=6.630$ \\
\hline & ISI (Dubai, UAE & $=0.829$ & РИНЦ (Russia) & $=0.156$ & PIF (India) & $=1.940$ \\
\hline & GIF (Australia) & $=0.564$ & ESJI (KZ) & $=8.716$ & IBI (India) & $=4.260$ \\
\hline & JIF & $=1.500$ & SJIF (Morocco) & $=5.667$ & OAJI (USA) & $=0.350$ \\
\hline
\end{tabular}

According to the Table 7, regression equations and correlation coefficients can be used to analyze the development of small business with the volume of lending-based financing to small businesses and private entrepreneurship entities. It is desirable to use the "excel" program. At the Republican level, the volume of goods and services (Y) created by the
CBRT sector in 2010-2017 will be calculated by the commercial banks for the impact of small business loans and microfinance services. 7 The results of the following regression analysis are based on the processing of the tablet data by computer using the Microsoft Excel program (Table 8).

Table 8. The result of regression analysis

\begin{tabular}{|l|l|}
\hline Regression statistics & \\
\hline Multitude R & 0,99281 \\
\hline R-square & 0,985673 \\
\hline Normalized R-square & 0,979942 \\
\hline Default error & 5136,445 \\
\hline Tracking & 8 \\
\hline
\end{tabular}

\begin{tabular}{||l|l|l|l|l|l|}
\hline Dispersion analysis & \multicolumn{2}{ll}{} \\
\hline & df & SS & MS & F - account & F - table \\
\hline \multicolumn{1}{|l|}{} & 2 & 9075247770 & 4537623885 & 171,9 & 2,45 \\
\hline Regression & 2 & 131915347,5 & 26383069,5 & & \\
\hline Remaining & 5 & 9207163117 & & & \\
\hline Total & 7 & & & & \\
\hline
\end{tabular}

\begin{tabular}{|l|l|l|l|l|}
\hline \multicolumn{2}{|l|}{ Regression statistics results } & \multicolumn{2}{l|}{} \\
\hline Variables & Coefficients & Default error & t- statistics & p- value \\
\hline Y- variable & 20477,7 & 5724,7 & 3,6 & 0,0 \\
\hline X1 & 6,1 & 10,8 & 0,6 & 0,04 \\
\hline X2 & $-0,4$ & 50,7 & 0,0 & 1,0 \\
\hline
\end{tabular}

Based on the results of Regression statistics, $\mathrm{Y}$ is the expression of the regression equation, which correlates the correlation between the factors (X1, X2) that affects the factor (s) using the least squares method:

$$
Y=6,1 X_{1}-0,4 X_{2}+20477,7
$$

Calculated $\mathrm{R}^{2}=0,985$

$F($ account $)=171,9>F($ жадвал $)=2,45$;

The result of the analysis is that $\mathrm{p}=0.99$, taken in X2, should be less than 0.05 . Therefore, the model adopted according to this variable is not intended. Thus, by deducting the variable $\mathrm{X} 2$ we find the effects of the variables separately:

$$
\begin{aligned}
& \mathrm{Y}=6,03 \mathrm{X}_{1}+20513,4 \\
& \mathrm{R}^{2}=0,985 ; F(\text { хссоб })=412,7>F(\text { table })=9,24
\end{aligned}
$$

This model testifies to the strong linkage between the size of bank loans and the development of small businesses. The results of the model will allow to increase the volume of production to 6 units in the amount of UZS 1 billion allocated to small businesses. This situation should set targeted strategies aimed at further expanding the practice of lending to small businesses and private entrepreneurship.

Also, the focus on the availability of highsecurity mortgage facilities in the crediting of small businesses contributes to the further increase in the volume of crediting of small businesses. This is due to the fact that the highly liquid mortgaged facilities that banks require are not available in most of the small businesses.

\section{Conclusion}

One of the problems posed by the problem of lending to investment projects of small businesses is the high level of investment credit attracted through foreign credit lines.

Lack of resources for small business lending in banks has a negative impact on the stability of cash 


\begin{tabular}{|c|c|c|c|c|c|c|}
\hline \multirow{4}{*}{ Impact Factor: } & ISRA (India) & $=3.117$ & SIS (USA) & $=0.912$ & ICV (Poland) & $=6.630$ \\
\hline & ISI (Dubai, UAE & $=0.829$ & РИНЦ (Russia & $=0.156$ & PIF (India) & $=1.940$ \\
\hline & GIF (Australia) & $=0.564$ & ESJI (KZ) & $=8.716$ & IBI (India) & $=4.260$ \\
\hline & JIF & $=1.500$ & SJIF (Morocco & $=\mathbf{5 . 6 6 7}$ & OAJI (USA) & $=0.350$ \\
\hline
\end{tabular}

flows of all undertakings, including small businesses. This is a low level of financial support of the economy, which does not allow solving problems of payments between business entities.

At the same time, there is a sharp contrast in the structure of loans issued by commercial banks to the sector of small businesses, which shows the growing rates of lending rates in developing sectors.

Taking into account the above, it is necessary to carry out the following work to increase the role of banks in the development of small business and private entrepreneurship:

- Taking into account the shortage of highly liquid mortgage facilities in small businesses, it is important to pay attention to crediting based on leasing, returnable lease and property liability insurance;

- increasing the share of the state in the authorized capital of banks and directing these resources to preferential crediting of small businesses in order to increase the volume of low interest loans issued to small businesses by commercial banks;

- Optimization of mechanisms of free money resources of large enterprises and organizations taking into account shortage of resources on short-term crediting of commercial banks by commercial banks;

- placement of free funds of the pension fund and state-owned insurance companies at low interest rates on commercial banks with the condition that they are channeled to crediting of small businesses;

- introduction of the calendar sequence of payments for these subjects to reduce the level of credit risk arising from overdraft and contocorrent crediting of small businesses.

Based on the above, the practical implementation of our proposal to increase the efficiency of crediting by small businesses in commercial banks will significantly increase the volume of their lending.

\section{References:}

1. (2017). The Decree of the President of the Republic of Uzbekistan from February 7, 2017 "About strategy of actions for further development of the Republic of Uzbekistan" for 2017-2021.

2. (2018). Resolution of the President of the Republic of Uzbekistan dated March 23, 2018 "On Additional Measures to Increase Public Officership of Banking Services" No. PP-3620/.

3. Beloglazova, G. N. (2010). Banking: retail business. Ucheb.posobie. Moscow: KnoRus.

4. Kurshakova, N. B. (2011). Bank marketing. Tutorial. Allowance. SPb: Peter.

5. Muratov, R. S., \& Pulatov, N. P. (2015, November-December). Mamlakat қtisodiotini modernization sharilish sharoitida kichik business korhonalalarini moryalashtirish mekhanlarari v istiқbollari. "It's an innovation tekhnologarar" or electronic magazine, №6. http://www.iqtisodiyot.uz/

6. Stiglitz, J., \& Weiss, A. (1981). 'Credit rationing in markets with imperfect information.' American Economic Review, vol. 71, pp. 393410.

7. Petersen, M., \& Rajan, R. (2000). 'Does distance still matter? The information revolution in small business lending,' University of Chicago Working Paper.
8. Berger, A., \& De Young, R. (2001). 'The effects of geographic expansion on bank efficiency.' Journal of Financial Services Research, vol. 19, forthcoming.

9. Feldman, R. (1997). 'Banks and a big change in technology called credit scoring.' The Region, Federal Reserve Bank of Minneapolis, September, pp. 19-25.

10. Alimardonov, I. (2018). Kichik business is a subject of credit crediting of amalies of assimilation of takomillashtirish. It is a tutorial of the Phanari Doctor (DSc) dissertation author's abstract. Uzbekistan Republican Bank-Moliya Academy. Toshkent.

11. Alimardonov, I. (2017, September-October). Kichik business subject molyashtirishning ayrim dolzarb masalalari. "It's an innovation tekhnologarar” or electronic magazine. №5.

12. Ibragimov, I. U., \& Tursunov, B. O. Enhancement the mechanism of analyzing of the methodological principles for the development and improvement of methods of assessment. Audit, № 4, pp. 11-13.

13. Tursunov, B. O. (2017). Osnovnye napravleniya podderzhki malogo biznesa $\mathrm{v}$ Uzbekistane i zarubezhnyy opyt razvitiya predprinimatel"stva. Audit, № 6, pp. 34-38.

14. (n.d.). Uzbekistan Republican Markaziy banks rasmy say. Retrieved 2019, from www.cbu.uz 